ZOOLOGIA 28 (6): 762-770, December, 2011

doi: $10.1590 /$ S1984-46702011000600009

\title{
Population ecology of small rodents and marsupials in a semi-deciduous tropical forest of the southeast Pantanal, Brazil
}

\author{
Cecilia S. de Andreazzi; Vitor Rademaker²; Rosana Gentile²; Heitor M. Herrera3,4; Ana M. \\ Jansen $^{3} \&$ Paulo S. D'Andrea ${ }^{2}$
}

\author{
${ }^{1}$ Campus Fiocruz da Mata Atlântica, FIOCRUZ. Estrada Rodrigues Caldas 3400, Pavilhão Agrícola, CJM, 22713-375 Rio de \\ Janeiro, RJ, Brazil. \\ ${ }^{2}$ Laboratório de Biologia e Parasitologia de Mamíferos Silvestres Reservatórios, FIOCRUZ. Avenida Brasil 4365, \\ 21045-900 Rio de Janeiro, RJ, Brazil. \\ ${ }^{3}$ Laboratório de Biologia de Tripanosomatídeos, FIOCRUZ. Avenida Brasil 4365, 21045-900 Rio de Janeiro, RJ, Brazil. \\ ${ }^{4}$ Centro de Pesquisa Agropecuária do Pantanal, EMBRAPA. Rua 21 de Setembro 1880, 79320-900 Corumbá, MS, Brazil. \\ ${ }^{5}$ Corresponding author. E-mail: dandrea@ioc.fiocruz.br
}

\begin{abstract}
The Pantanal is a South American biome characterized by extensive plains and stark environmental seasonality. Several habitats are subject to annual flooding, forcing small mammal species to aggregate in dry forest patches, which most likely influences their population dynamics and life history strategies. In order to investigate the seasonal influence on the life history traits of these small mammals, we conducted a 2-year mark-recapture study in the southeastern region of the Brazilian Pantanal (Nhecolândia) and analyzed the population dynamics of the most abundant small mammal species with the jackknife estimator. A trapping effort of 21,560 trap-nights resulted in 615 individuals in 1,171 captures (success $=5.43 \%$ ). Three species of rodents - Oecomys mamorae (Thomas, 1906), Thrichomys pachyurus (Wagner, 1845), and Clyomys laticeps (Thomas, 1841) - and three species of marsupials - Gracilinanus agilis (Burmeister, 1854), Thylamys macrurus (Olfers, 1818), and Monodelphis domestica (Wagner, 1842) - were obtained. The most abundant species was $O$. mamorae, followed by G. agilis and T. pachyurus. Oecomys mamorae was more abundant in the wet season and presented an opportunistic reproductive strategy. Gracilianus agilis displayed increased population sizes in the dry season and synchronized, seasonal reproduction during the rainy season. Thrichomys pachyurus had a small population size, delayed response to variations in environmental conditions and higher reproductive rates in the dry season. All species revealed different life history strategies (seasonal, opportunistic or delayed response to environmental variations), coinciding with periods of higher resource availability in order to maximize survival.
\end{abstract}

KEY WORDS. Gracilinanus agilis; Oecomys mamorae; population dynamics; seasonality; small mammal; Thrichomys pachyurus.

The Pantanal is a vast, flat wetland located in central South America, composed of a mosaic of habitats. The region is subject to annual, summer flooding, during which much of the Pantanal becomes inundated (ADÁmoli 1987), thus confining animals to small areas (Keuroghlian et al. 2009). This pattern has several consequences for the local fauna related to habitat and resource availability. The Pantanal also suffers continuous human interventions such as controlled burning and deforestation due to expansion of agriculture and cattle breeding activities (SeIdL et al. 2001, Harris et al. 2005), which are responsible for alteration of the natural regional environmental characteristics (HARRIs et al. 2005).

Population fluctuations of tropical small mammals are often related to temporal variations in environmental variables associated with resource availability (BERGALLo 1994, ADLER 1998, Bergallo \& Magnusson 1999, Gentile et al. 2004, Mendel et al.
2008), which may influence survival and reproduction. Species adaptation to different climatic and environmental conditions together with individual selection should favor reproduction at times of maximum offspring survival (BAKER 1938), which can vary seasonally.

Sigmodontine rodent populations, generally opportunistic, have the following characteristics: high densities, reduced survivorship, rapid population turnover and population growth as a response to greater resource availability (FonseCA \& KiERULFF 1989, Bergallo 1995, Bergallo \& Magnusson 1999, Gentile et al. 2000, Cerqueira 2005). On the other hand, Neotropical marsupials usually exhibit synchronized, seasonal reproduction near the end of the dry season rendering a denser population in the rainy season (Fleming 1973, Tyndale-Biscoe \& Mackenzie 1976, O’Connell 1989, Cerqueira et al. 1993, Cerqueira \& Bergallo 1993, Bergallo \& Cerqueira 1994, Bergallo 1994, Cáceres \& Monteiro- 
Filho 1998, Gentile et al. 2000, Lima et al. 2001, Gentile et al. 2004, D'ANDrea et al. 2007). This allows weaning and recruitment peaks to occur during the rainy periods when resources are most abundant (Rademaker \& Cerqueira 2006). However, some small mammal populations may have a strong densitydependent regulation and a delayed response to environmental variations, such as the echimyid rodents which posses longer life spans, longer gestation periods and fewer offspring when compared to sigmodontines (RoberTs et al. 1988, BERGAllo 1995, TeiXeira et al. 2005, OAKs et al. 2008).

Population studies of small rodents and marsupials in the Pantanal biome have been few and far between as well as for short periods of time (SCHALler 1983, LACHer \& AlHo 1989, Herrera et al. 2007, Aragona \& Marinho-Filho 2009), none having been conducted in the southeast region (Nhecolândia). Reproduction of most species begins at the end of the dry season and is intensified during the wet season in the northern Pantanal (Aragona \& Marinho-Filho 2009). However, this region displays several features strongly associated to Cerrado physiognomies, featuring drier areas in comparison to the southeast Pantanal (AdÁmoli 1987).

Herein, we investigate the influence of seasonality on life history strategies of the region's most abundant rodents and marsupials, i.e., Oecomys mamorae (Thomas, 1906) (Rodentia: Sigmodontinae), Thrichomys pachyurus (Wagner, 1845) (Rodentia: Echimyidae) and Gracilinanus agilis (Burmeister, 1854) (Didelphimorphia: Didelphidae), in a two-year population study in southeast Pantanal (Nhecolândia Region). We then characterize the population dynamics, reproduction patterns and life history strategy of each species, considering their evolutionary consequences.

\section{MATERIAL AND METHODS}

The study was carried out in Rio Negro farm $\left(19^{\circ} 48^{\prime}\right.$ $19^{\circ} 57^{\prime} \mathrm{S}$ and $\left.56^{\circ} 19^{\prime}-56^{\circ} 26^{\prime} \mathrm{W}\right)$, situated in the southeast of the Nhecolândia region of the Brazilian Pantanal, state of Mato Grosso do Sul (Silva \& AbDON 1998). The area is a 7700 ha private reserve of native vegetation consisting of patches including seasonal semi-deciduous and deciduous forest as well as savanna, interspersed with innumerable, small fresh, brackish and even saltwater lakes and ponds (ABDon et al. 1998, Nunes DA CunHa et al. 2006).

Trapping was conducted in the "Cordilheiras", which are sinuous remains of paleo-levees several kilometers in length about $100 \mathrm{~m}$ wide, reaching 1-2 $\mathrm{m}$ above the surrounding bodies of water and seasonally inundated plains. These elevations are not subject to flooding and are covered by dense, semi-deciduous forest vegetation. Trees are predominantly species from the Cerrado (Brazilian savanna), with a $6 \mathrm{~m}$ high canopy and a few emergent trees reaching $30 \mathrm{~m}$ height (NunES DA CunHa et al. 2006, Rodela \& Queiroz-Neto 2007). The climate is sub-humid tropical, characterized by dry winters and rainy summers (NIMER
1989). The monthly average temperature and rainfall on the Rio Negro farm varied during the two year study period from 21.2 to $32.3^{\circ} \mathrm{C}$ and 0 to $389 \mathrm{~mm}$, respectively (Fig. 1).

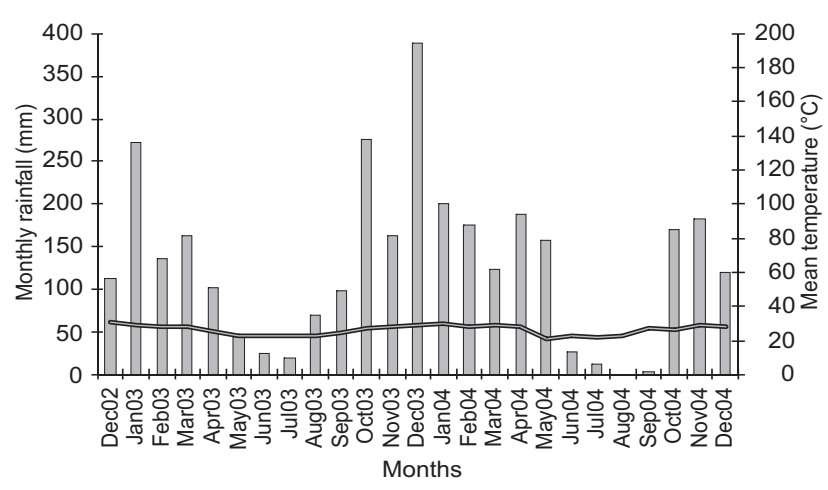

Figure 1. Monthly rainfall (bars) and monthly mean temperature (line) in Rio Negro farm from December 2002 to December 2004 (data provided by Donald P. Eaton, Earthwatch Institute).

A previous removal capture for species identification had been previously carried out in this locality. Collected animals were deposited as voucher specimens in the Museu Nacional, Rio de Janeiro, Brazil and some were kept in the temporary collection of the Laboratório de Biologia e Parasitologia de Mamíferos Silvestres Reservatórios, Fiocruz. All species were identified based on morphology and/or karyotype. Capture-markrecapture sessions were undertaken for seven consecutive nights on four plots during 2003 and 2004. In plots 1 and 2, trapping sessions occurred every three months. In plots 3 and 4 , traps were placed every three months in 2003 and every six months in 2004. Each plot consisted of four line transects, three inside the forest and one on the forest edge. In each plot, transects were randomly marked, respecting a distance of $200 \mathrm{~m}$ apart from each other. The distance between plots was $2 \mathrm{~km}$. Each transect had 10 trapping stations $20 \mathrm{~m}$ apart. Two traps were placed at each station next to each other, one Tomahawk ${ }^{\circledR}$ (model 201, $40.6 \times 12.7 \times 12.7 \mathrm{~cm}$ ) and one Sherman ${ }^{\circledR}$ (model XLK $7.6 \times 9.5 \times 30.5 \mathrm{~cm}$ ). In the forest transects, one additional trap was placed in a tree at each station, a Tomahawk ${ }^{\circledR}$ trap for odd-numbered stations and a Sherman ${ }^{\circledR}$ trap for even-numbered stations. Traps were baited with a mixture of banana, peanut butter, oatmeal and bacon and checked daily every morning.

Each captured animal was marked with two individual ear tags, and species data were recorded, i.e. sex, breeding condition, body mass, body length, dental development (marsupials only), general remarks and trap characteristics (model, station, location). All animals were later released at the capture stations.

Capture procedures of animals were in accordance with the American Guidelines for the Capture, Handling and Care of Mammals (SIKEs et al. 2011). Captures were under the autho- 
rization of the Instituto Brasileiro do Meio Ambiente e dos Recursos Naturais Renováveis (IBAMA).

Population parameters (size, survival, recruitment rates) were estimated using data from plots 1 and 2 only, because plots 3 and 4 were not sampled in May and November 2004. For reproduction and age structure analyses, we used data from all plots.

Sex ratio biases from the expected 1:1 were tested for each species with chi-square tests (ZAR 1999). The preference for trap type and location (Sherman or Tomahawk, and ground or tree) were tested using the contingency chi-square tests (ZAR 1999) for each species.

Pollock's robust design (Pollock 1982) was adopted to estimate population parameters. Population sizes were estimated with the Nh "jackknife" estimator (Burnham \& Overton 1979). Survival and recruitment rates of $O$. mamorae were estimated for the periods between consecutive sessions by the Jolly-Seber method (BEGON 1979, SEBER 1986), correcting for different periods of time (FERNANDEZ 1995). However, the data for T. pachyurus and G. agilis were insufficient for these estimators. The survival rate for these species was estimated as the proportion of the MNKA (minimum number of individuals known to be alive) at time " $\mathrm{t}_{\mathrm{i}+1}$ " relative to the MNKA at the previous time " $\mathrm{t}_{\mathrm{i}}$ ". The recruitment rate was estimated as the proportion of individuals that were not caught before time " $\mathrm{t}_{\mathrm{i}+1}$ " relative to the MNKA at time " $\mathrm{t}_{\mathrm{i}}$ ".

Female rodents were considered breeding if pregnant, lactating, or presenting opened vaginas or copulatory plugs. Female marsupials were considered breeding when presenting one or more of the three following conditions: (I) pouched young, (II) swollen nipples or (III) evidence of lactation.

Seasonal variations in age structure were analyzed for each species by dividing them into three age classes. Marsupials were classified as young, subadult or adult depending upon their dental condition. Specimens with complete upper and lower dentition were considered adults, those with the third permanent premolar present but missing the last upper and/or lower molar as subadults and those with the deciduous premolar as young.

For O. mamorae, animals were separated into three age classes by sex depending upon their body mass and sexual maturity (Tab. I). Thrichomys pachyurus were divided into three age classes based on their weight growth curve (TeIXeIRA et al. 2005, Tab. I).

Table I. Age classes of Oecomys mamorae and Thrichomys pachyurus, estimated by body mass for each sex.

\begin{tabular}{clcc}
\hline \multirow{2}{*}{ Species } & \multirow{2}{*}{ Age class } & \multicolumn{2}{c}{ Body mass $(\mathrm{g})$} \\
\cline { 2 - 4 } & & Female & Male \\
\hline O. mamorae & Young & $<36^{\mathrm{a}}$ & $<30^{\mathrm{c}}$ \\
& Subadult & $36<64^{\mathrm{b}}$ & $30<79^{\mathrm{d}}$ \\
& Adult & $>64$ & $>79$ \\
\multirow{2}{*}{ T. pachyurus } & Young & $<120$ & $<120$ \\
& Subadult & $120<250$ & $120<250$ \\
& Adult & $>250$ & $>250$ \\
\hline
\end{tabular}

${ }^{\mathrm{a}}$ minimum weight of females with open vagina; ${ }^{\mathrm{b}}$ maximum weight of females with closed vagina; ${ }^{c}$ minimum weight of males with scrotal testes; ${ }^{d}$ maximum weight of males with abdominal testes.

\section{RESULTS}

During the study, a trapping effort of 21,560 trap-nights resulted in 1,171 captures of 615 individuals (success $=5.43 \%$ ). Capture success did not differ between seasons $\left(\chi^{2}=0.129, \mathrm{p}>\right.$ $0.5)$. The most abundant species was $O$. mamorae followed by G. agilis and T. pachyurus (Tab. II). Seventy nine percent of the O. marmore, $87 \%$ of the G. agilis and $91 \%$ of the T.pachiurus were captured in only one trapping season.

The number of captures of $O$. mamorae was independent of trap type $\left(\chi^{2}=0.391, \mathrm{p}>0.05\right.$, Tab. II), but the frequency was greater in trees $\left(\chi^{2}=140.06, \mathrm{p}<0.001\right)$. T. pachyurus was captured predominantly in Tomahawk traps $\left(\chi^{2}=67.17\right.$, $\mathrm{p}<0.001)$ on the ground $\left(\chi^{2}=16.75, \mathrm{p}<0.001\right.$, Tab. II). $G$. agilis was captured only in Sherman traps significantly more often in trees $\left(\chi^{2}=13.42, \mathrm{p}<0.001\right)$.

Oecomys mamorae had higher population sizes during the second year of the study, with smaller population sizes in De-

Table II. Total number of individuals, captures, mean number of captures per individual, number of males and females captured, number of captures per trap type, and location (ground/tree) of each species recorded in the Rio Negro farm, Aquidauana, from February 2003 to November 2004. (Sh) Sherman, (Tw) Tomahawk, (Caps) captures.

\begin{tabular}{lcccccc}
\hline \multicolumn{1}{c}{ Species } & Total individuals & Total caps & Captures/Individuals & Sex ratio (M/F) & Trap Sh/Tw & Trap location Ground/Tree \\
\hline O. mamorae & 343 & 575 & 1.68 & $166 / 161$ & $295 / 280$ & $173 / 402^{*}$ \\
G. agilis & 123 & 248 & 2.02 & $70 / 47^{*}$ & $248 / 0$ & $133 / 115^{*}$ \\
T. pachyurus & 84 & 198 & 2.36 & $44 / 32$ & $16 / 99^{*}$ & $110 / 5^{*}$ \\
C. laticeps & 28 & 62 & 2.21 & $12 / 13$ & $14 / 20$ & $34 / 0^{*}$ \\
T. macrurus & 27 & 74 & 2.74 & $13 / 11$ & $71 / 3^{*}$ & $49 / 25$ \\
M. domestica & 10 & 14 & 1.40 & $5 / 5$ & $10 / 4$ & $14 / 0^{*}$ \\
\hline
\end{tabular}

* Significantly different. 
cember 2003 and August 2004 (Fig. 2). Recruitment decreased in the dry periods, whereas survival increased at the beginning of the wet season and decreased at the end of the wet season when recruitment started to rise. Females in reproductive condition were captured all year round, although in higher proportions during the wet season, from December 2003 to November 2004 (Fig. 3). Reproduction as well as recruitment of young (Fig. 4) was higher during the rainy season, resulting in an increase in population size at the end of the wet season. No young were observed in May 2003 and August 2004, during the dry season (Fig. 4).
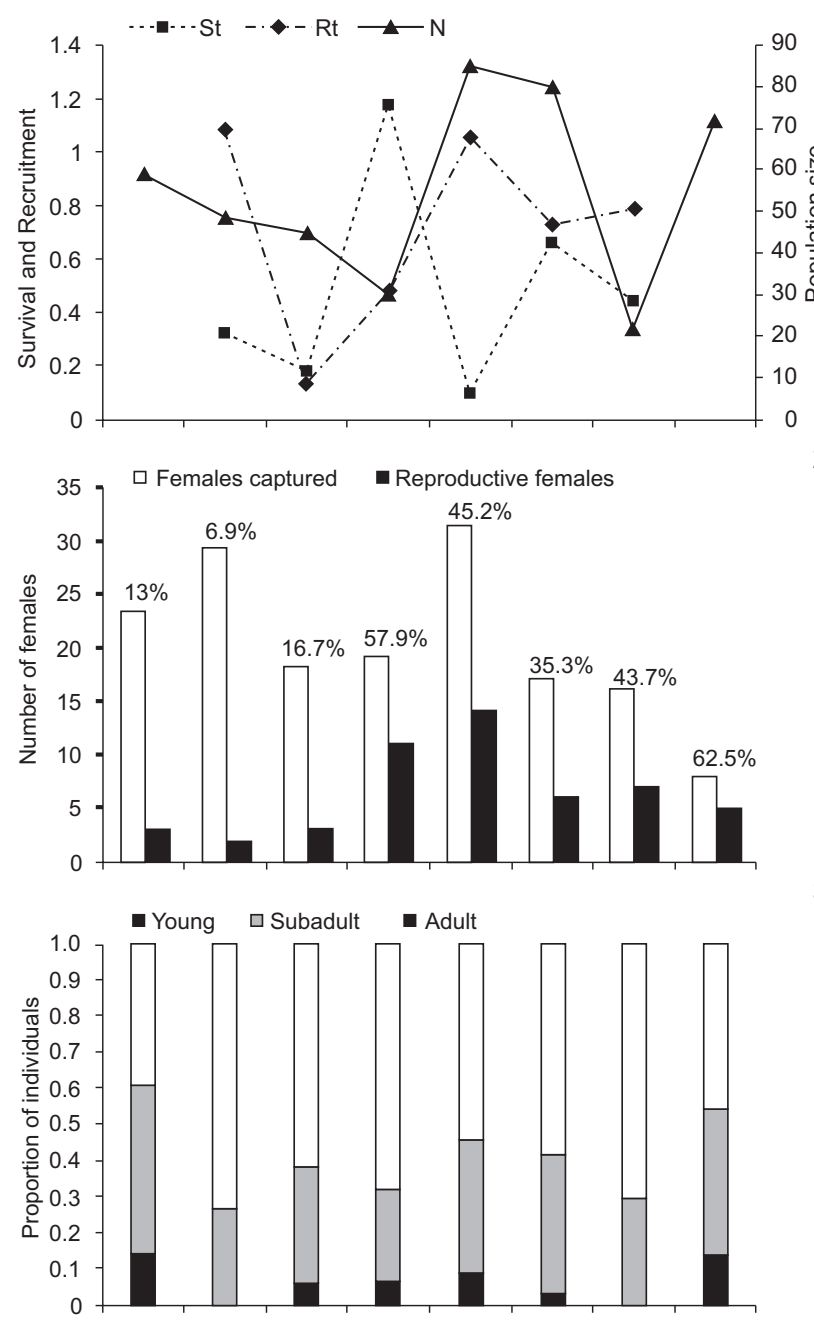

Feb/03 May/03 Aug/03 Dec/03 Feb/04 May/04 Aug/04 Nov/04

Figures 2-4. Oecomys mamorae population size $(\mathrm{N})$, survival $(\mathrm{St})$ and recruitment (Rt) rates (2); total number of females captured, number of reproductive females and the proportion of reproductive females (3); and the proportion of individuals on each age classes (4); in the Rio Negro farm, Aquidauana, from February 2003 to November 2004.
The survival rate of T. pachyurus was low for the entire study (estimated values 0-26\%, Fig. 5). Therefore, low population size was maintained mainly by recruitment, which was high throughout the study (Fig. 5). Given that recruitment was measured as the proportion of new individuals captured and trapping took place every three months, the addition of new members through reproduction could not be distinguished from those by immigration. Reproducing females appeared throughout the year, with higher proportions in the dry season (Fig. 6). Young animals were predominantly captured during the rainy season, and none were captured in the mid-dry season - August (Fig. 7).
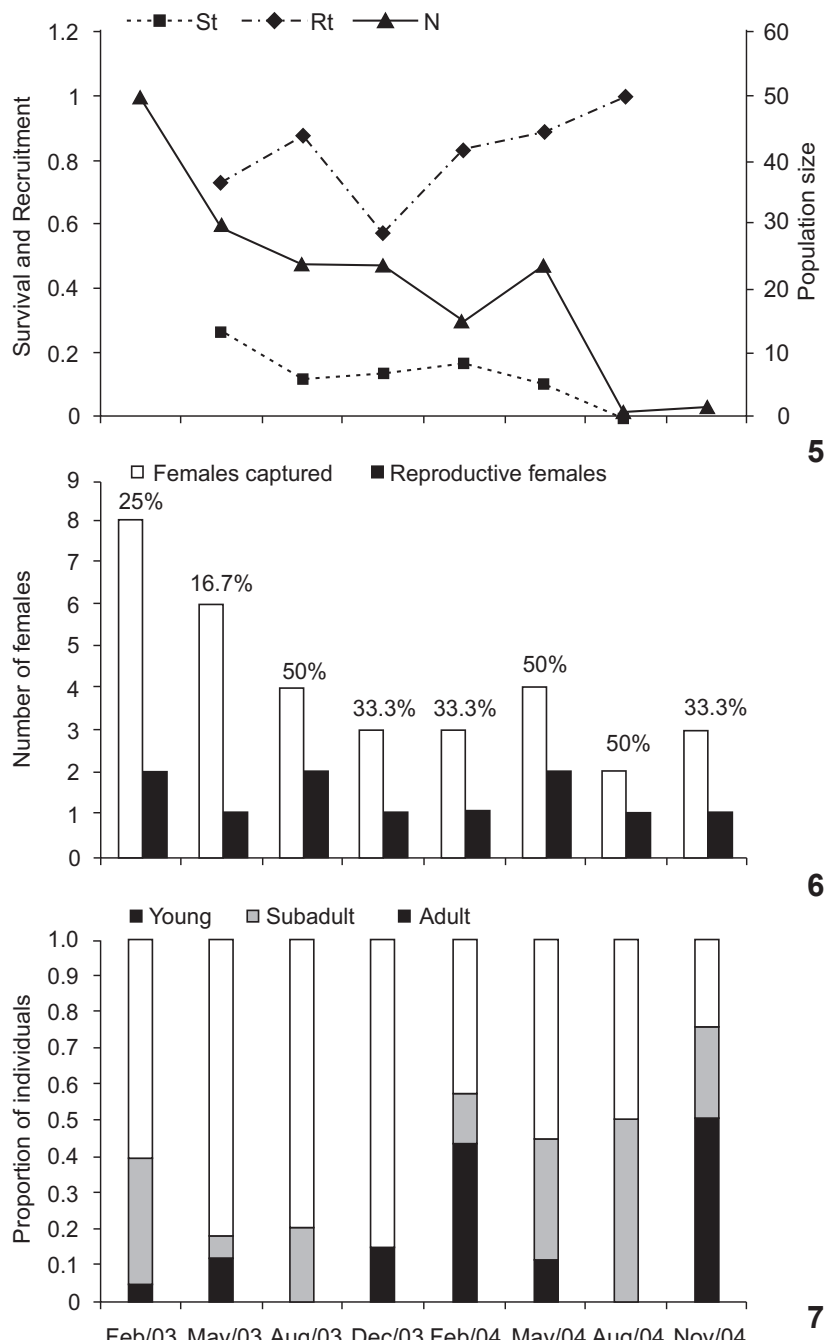

6

Figures 5-7. Thrichomys pachyurus population size (N), survival (St) and recruitment (Rt) rates (5); total number of females captured, number of reproductive females and the proportion of reproductive females (6); and the proportion of individuals on each age classes (7); in the Rio Negro farm, Aquidauana, from February 2003 to November 2004. 
Gracilinanus agilis was the only species that demonstrated biased sex ratios, with significantly more captures of males than females $\left(\chi^{2}=4.52, p=0.03\right.$, Tab. II). This species displayed a low population size except for May to August 2003, when it increased 5 to 20 fold, respectively, from the initial population in February 2003 (Fig. 8). This increase was attributable to high recruitment in May 2003, as a result of breeding activity during the wet season (December-February, Fig. 9). The peak was followed by a decrease due to lower recruitment which was not repeated in 2004, when the population remained low all year (Fig. 8). Lower survival rates occurred after the reproductive period, when recruitment increased. Only G. agilis adults were captured during the study, except for one subadult in November 2004. There were no recaptures between reproductive seasons.
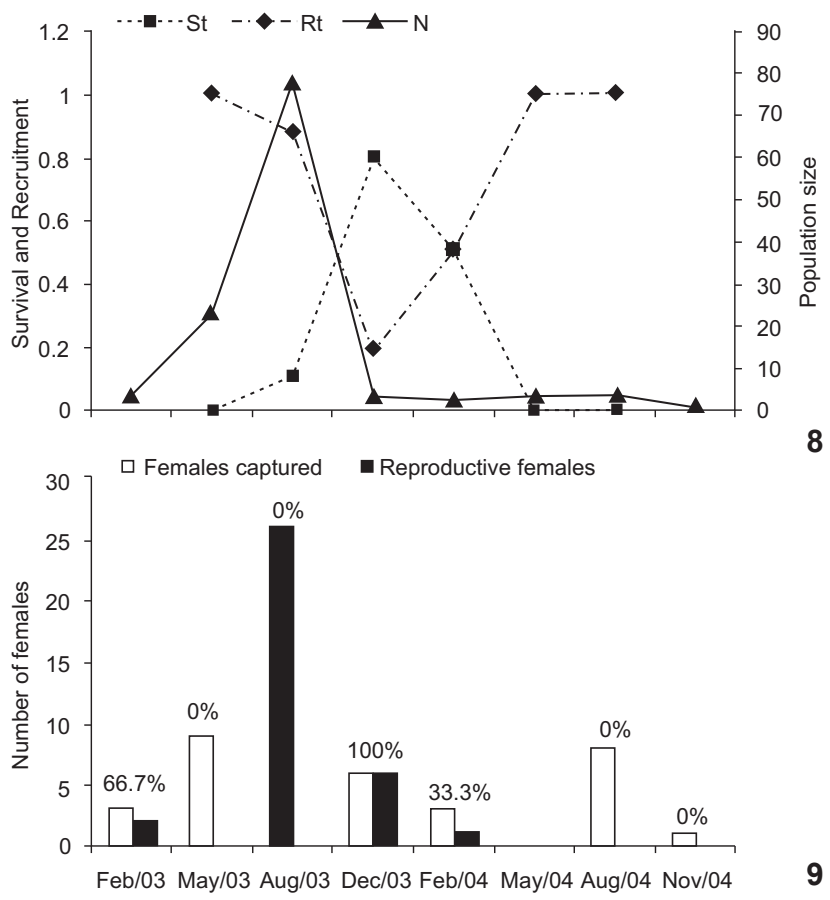

Figures 8-9. Gracilinanus agilis population size $(\mathrm{N})$, survival (St) and recruitment (Rt) rates (8); and total number of females captured, number of reproductive females and the proportion of reproductive females (9); in the Rio Negro farm, Aquidauana, from February 2003 to November 2004.

Clyomys laticeps (Thomas, 1841) (Rodentia: Echimyidae), Thylamys macrurus (Olfers, 1818) and Monodelphis domestica (Wagner, 1842) (Didelphimorphia: Didelphidae) were rarely captured during this study but were present in most trapping sessions (Tab. II). Monodelphis domestica and C. laticeps were exclusively captured on the ground $\left(\chi^{2}=9.33\right.$ and $\chi^{2}=22.67$ respectively, both $\mathrm{p}<0.001)$, regardless of trap type $\left(\chi^{2}=2.51\right.$ and $\chi^{2}=0.71$ respectively, both $\left.0.5>\mathrm{p}>0.1\right)$ and $T$. macrurus was predominantly captured in Sherman traps $\left(\chi^{2}=60.67\right.$, $p<0.001)$, regardless of position $\left(\chi^{2}=0.51, p>0.5\right)$.

\section{DISCUSSION}

Studies conducted in markedly seasonal habitats such as the Venezuelan Llanos (August 1983, 1984, Vivas \& Calero 1985, 1988, Vivas 1986, Soriano \& Clulow 1988, O'Connell 1989), the Cerrado gallery forests (Mares \& ERNest 1995, Vieira 1997) and the Poconé Pantanal (Aragona \& Marinho-Filho 2009) have confirmed that small mammal populations are influenced by seasonal dynamics. In this study, the three most abundant species had population dynamics influenced by the seasonality of the Pantanal, each in different ways.

The population dynamics of O. mamorae reflected an opportunistic pattern, which is common in other sigmodontine rodents in the Neotropics (Fonseca \& KierulfF 1989, Gentile et al. 2000, Cerqueira 2005). Population size varied throughout the year, decreasing in the dry season and increasing in the wet season due to increased recruitment and survival rates. Other Oecomys spp., such as O. concolor and O. bicolor, also demonstrated opportunistic reproduction in Cerrado gallery forests (MARES \& ERNEST 1995). However, reproduction was restricted to the rainy season. Greater abundance during the rainy season of Sigmodon hispidus (Say and Ord, 1825), another sigmodontine, in the Venezuelan Llanos was attributed to high primary productivity during this period (VIVAS \& CALERO 1985, 1988). It was also argued that strong seasonality, which in turn was dictated by rainfall, could promote an annual cycle due to food and habitat availability. Although we have no simultaneous quantitative assessment of resource availability in the study area, in the Brazilian Pantanal there are many trees with ripening fruits during the rainy season (Ротт \& Ротт 1994). Given that Oecomys spp. is essentially frugivorous-granivorous (EISENBERG \& REDFord 1999, Marinho-Filho et al. 2002, Vieira et al. 2003), the greater abundance of $O$. mamorae in the rainy season could be related to resource availability, resulting in higher recruitment rates. High survival rates during the dry season may be due to perennial fruit-bearing trees, such as the "acuri", (Attalea phalerata Mart. ex Spreng.) and "bocaiúva', Acrocomia aculeata (Jacq.) Lodd. ex Mart. palms, which produce fruits in periods of scarcity (Keuroghlian et al. 2009). Thus, the life history of O. mamorae may follow a pattern in which female reproduction and population size could be determined by resource levels.

Thrichomys pachyurus had a different population pattern. Although it also reproduced throughout the year, its reproduction was predominantly during the dry season, with the population exhibiting a delayed response to resource and environmental variations. Due to a comparatively long gestation (105 days) and generation time (ca. five months) as well as small litter size (2.5 \pm 0.9 young; Teixeira et al. 2005), we found, as expected, slower responses in this species than in the 
opportunistic O. mamorae. The intense, longer rainy season in 2003 may have negatively influenced the T. pachyurus population in the following year due to the reduction of available habitat for this mostly terrestrial species. This, in turn, led to low survival rates in 2003 and an increase in reproductive rates in the second year, following a density-dependent feedback process, in which the reproduction would increase due to reduced population sizes. Population patterns of this species will be clearer with additional long-term studies.

The G. agilis population had synchronized seasonal reproduction during the rainy season, similar to other didelphids (August 1984, Vivas \& Calero 1985, O’Connell 1989, Cáceres \& Monteiro-Filho 1998, Gentile et al. 2004, Rademaker \& Cerqueira 2006, LEINER et al. 2008, BONECKER et al. 2009). Seasonal didelphid reproduction associated with warm, wet seasons has been correlated with the influence of rainfall on insect abundance (Pinheiro et al. 2002, Gentile et al. 2004). Thus, proportions of pregnant and lactating females as well as growth rates of juveniles increase in response to higher food abundance during the wet season (MARTins et al. 2006). Final phases of lactation and post-weaning are the most critical periods for marsupial reproduction due to larger energetic demands (LeE \& COCKBURN 1985), and they should coincide with periods of greater food availability. In the Brazilian Cerrado, G. agilis (MARES \& ERNEST 1995) and Gracilinanus microtarsus (Wagner, 1842)(MarTINs et al. 2006) showed a similar pattern with reproduction at the end of the dry season and larger populations in the rainy season due to juvenile and subadult recruitment. Aragona \& MARINHO-FILHO (2009) reported higher reproductive activity for G. agilis in the late dry season and in the beginning of the rainy season and larger populations during the dry season, in the Brazilian Pantanal of Poconé.

In spite of the presence of reproductive females of $G$. agilis during the study, almost no juveniles were captured. One possible explanation is trap bias favoring adult trappings. Increased abundance associated with low reproductive activity during the 2003 wet season could indicate immigration, as there was high recruitment. We also must consider that a threemonth time interval between trapping sessions may be very long for this species and some reproductive events could have been undetected Moreover, semelparity and short life span have been reported for several small opossums, such as Marmosops incanus (Lund, 1840) (LoRINi et al. 1994), Marmosops paulensis (Tate, 1931) (LeIner et al. 2008), G. microtarsus (Martins et al. 2006) and Monodelphis dimidiata (Wagner, 1847) (PINE et al. 1985), and this could explain reduction of survival after the reproductive period.

The male-biased sex ratio in G. agilis was probably the result of high numbers of males captured during the 2003 dry season, when population sizes of this species were higher. Males of this species display a more exploratory and vagrant behavior, thus leading to more captures and larger body size when compared with females (MarTins et al. 2006).
The seasonal flooding around the "Cordilheiras" may have different effects in each mammal population in the Pantanal. During the rainy season, the lower plains that surround the "Cordilheiras" are submerged, resulting in a greater aggregation in the non-flooded forest patches (ANDERSEN et al. 2000). In the present study, we observed that species which mainly used the upper strata of the "Cordilheiras" and were seldom captured on forest edges, such as O. mamorae and G. agilis (unpub. data), should be less affected by seasonal flooding, because their populations were restricted to the "Cordilheiras" all year long. In the case of T. pachyurus, it is expected that its population should be more affected by seasonal flooding as it is primarily a terrestrial species that also uses the seasonally flooded grasslands surrounding the "Cordilheiras" (Herrera et al. 2007). The increased density of $T$. pachyurus during the rainy season may increase intraspecific competition, which would be a density-dependent factor regulating the population.

Small mammal richness found in this study (six species) was lower than that of previous studies in the Nhecolândia Pantanal (Alho et al. $1987 \mathrm{n}=7$, Alho et al. $2000 \mathrm{n}=10$, Herrera et al. $2007 \mathrm{n}=10)$. Thylamys macrurus was not recorded by AlHo et al. (1987, 2000), whereas Cavia aperea (Erxleben, 1777), Calomys callosus (Rengger, 1830), Oryzomys concolor (= Oecomys sp. (Thomas, 1906)), Oryzomys fornesi (= Oligoryzomys fornesi (Massoia, 1973)), Oryzomys subflavus (Wagner, 1842) and Rhipidomys mastacalis (Lund, 1840) were. These differences may reflect different characteristics of the habitat among the sites. Herrera et al. (2007) also captured Holochilus brasiliensis (Desmarest, 1819), Oryzomys scotti (Langguth and Bonvicino, 2002), C. callosus and Philander frenatus (Olfers, 1818) on the Rio Negro farm. Since we sampled only the "Cordilheiras", and small mammals are highly selective in relation to their microhabitats, the species composition we have documented here is related to this habitat. Other studies have sampled not only the "Cordilheiras", but also the Cerrado sensu stricto, gallery forest, lake edges, grasslands and household surroundings. The Nhecolândia region has important habitat differences with respect to seasonality, land use and conservation, with the east being more influenced by large rivers crossing the region (RoDELA \& Queiroz Neto 2007). This is the first study of small mammal population dynamics in the east side of this region.

The reproductive strategy of a population is crucial for its maintenance, especially in seasonal environments. A higher frequency of reproduction during a certain period of the year in response to some seasonal variation in resource availability may offer an ecological advantage to those animals and, consequently, an evolutionary gain to their populations. Among the studied species, the mouse opossum (Gracilinanus agilis), the arboreal rice rat (O. mamorae) and the spiny rat ( $T$. pachyurus) had their life history traits influenced by the marked seasonality of the Pantanal environment. The strategies of these three species (seasonal, opportunistic, or delayed response) result in the coincidence of weaning with periods of greater 
resource availability, thus maximizing survival in the Pantanal, where "Cordilheiras" act as forest islands during the rainy season. Further studies evaluating seasonal movements of the individuals and the implications on inter and intraspecific competition would improve the understanding of these questions.

\section{ACKNOWLEDGEMENTS}

To Diogo Loretto, Natalie Olifiers, Samantha T. Mansur, Tatiana P.T. Abreu and staff from the Laboratório de Biologia e Parasitologia de Mamíferos Silvestres Reservatórios FIOCRUZ/ RJ who helped us during field work. Cibele Bonvicino for karyotype identiûcation of small mammal species. Claudio Bidau and Fernando Fernandez for important contributions. This work was supported by the Conselho Nacional de Pesquisas e Desenvolvimento, Instituto Oswaldo Cruz/Fiocruz, Conservação Internacional do Brasil, Earthwatch Institute and FUNDECT. The assistance provided by Alexine Keuroghlian, Donald P. Eaton and by the local inhabitants is gratefully acknowledged, especially the Rio Negro farm staff.

\section{LITERATURE CITED}

Abdon, M.M.; V.J PotT \& J.S.V Silva. 1998. Evaluation of aquatic vegetation on ponds of Nhecolândia subregion in the Pantanal through Landsat and SPOT data. Pesquisa Agropecuaria Brasileira 33: 1675-1681.

AdÁmolı, J. 1987. Fisiografia do Pantanal, p. 15-18. In: A.C. Allem \& J.F.M. Valls (Eds). Recursos forrageiros do Pantanal Matogrossense. Brasília, Embrapa-Cenargen-CPAP.

ADLER, G.H. 1998. Impacts of resource abundance on populations of a tropical forest rodent. Ecology 79: 242-254. doi: 10.1890/ 0012-9658(1998)079[0242:IORAOP]2.0.CO;2.

Alho, C.J.R.; T.E Lacher Jr; Z.M.S. Campos \& H.C Gonçalves. 1987. Mamíferos da Fazenda Nhumirim, sub-região de Nhecolândia, Pantanal do Mato Grosso do Sul: Levantamento preliminar de espécies. Revista Brasileira de Biologia 4: 151-164. doi: 10.1590/S0101-81751987000200007

Alho, C.J.R.; C.R. Strưssmann \& L.A.S Vasconcellos. 2000. Indicadores da magnitude da diversidade e abundância de vertebrados silvestres do Pantanal num mosaico de habitats sazonais, p. 1-54. In: III Simpósio sobre Recursos Naturais e Sócio-Econômicos do Pantanal. Corumbá, Centro de Pesquisa Agro-Pecuária da EMBRAPA.

Andersen,D.C.; K.R. Wilson; M.S. Miller \& M. Falck. 2000. Movement Patterns of Riparian Small Mammals During Predictable Floodplain Inundation. Journal of Mammalogy 81:1087-1099. doi: 10.1644/1545-1542(2000)081<0852:ANSOPG >2.3.CO;2

Aragona, M. \& J. Marinho-Filho. 2009. História natural e biologia reprodutiva de marsupiais no Pantanal, Mato Grosso, Brasil. Zoologia 26: 220-230. doi: 10.1590/S198446702009000200004 .
August, P.V. 1983. The role of habitat complexity and heterogeneity in structuring tropical mammal communities. Ecology 64: 1495-1507. doi:10.2307/1937504

August, P.V. 1984. Population ecology of small mammals in the Llanos of Venezuela, p. 71-104. In: R.E. MARTIN \& B.R. CHAPMAN (Eds). Contributions in mammalogy in honor of Robert $\mathrm{L}$. Packard. Lubbock, Texas Tech University Museum, Special Publications, 234p.

BAKER, J.R. 1938. The evolution of breeding seasons, p. 161177. In: G.R. DE BEER (Ed.). Evolution: Essays on Aspects of Evolutionary Biology. Clarendon Press, Oxford.

BEGON, M. 1979. Investigating Animal Abundance: CaptureRecapture for Biologists. London, Edward Arnold, 97p.

Bergallo, H.G. 1994. Ecology of a small mammal community in an Atlantic Forest area in southeastern Brazil. Studies on Neotropical Fauna and Environment 29: 197-217.

Bergallo, H.G. \& R. Cerqueira. 1994. Reproduction and growth of Monodelphis domestica in Northeastern Brazil. Journal of Zoology 232: 551-563.

Bergallo, H.G. 1995. Comparative life-history characteristics of two species of rats, Proechimys iheringi and Oryzomys intermedius, in an Atlantic Forest of Brazil. Mammalia 59: 51-64.

Bergallo, H.G. \&W.E. Magnusson. 1999. Effects of climate and food availability on four rodent species in southeastern Brazil. Journal of Mammalogy 80: 472-486.

Bonecker, S.T.; L.G. Portugal; S.F. Costa-Neto \& R. Gentile. 2009. A long-term study of small mammal populations in a Brazilian agricultural landscape. Mammalian Biology 74: 467-477. doi: 10.1016/j.mambio.2009.05.010.

Burnham, K.P. \& W.S Overton. 1979. Robust estimation of population size when capture probabilities vary among animals. Ecology 60: 927-936. doi:10.2307/1936861.

Cáceres, N.C. \& E.L.A. Monteiro-Filho. 1998. Population dynamics of the common opossum, Didelphis marsupialis (Mammalia, Marsupialia), in Southern Brazil. Zeitschrift für Saugetierkunde 63: 169-172.

Cerqueira, R. \& H.G. Bergallo. 1993. A possible case of photoperiod controlling the reproduction of a South American marsupial. Ciencia e Cultura 45: 140-141.

Cerqueira, R.; R. Gentile; F.A.S. Fernandez \& P.S. D'Andrea. 1993. A ûve year population study of an assemblage of small mammals in Southeastern Brazil. Mammalia 57: 507-517.

Cerqueira, R. 2005. Fatores ambientais e a reprodução de marsupiais e roedores no leste do Brasil. Arquivos do Museu Nacional do Rio de Janeiro 63: 29-39.

D'Andrea, P.S.; R. Gentile; L.S. Maroja; F.A. Fernandes; R.S. Coura \& R. Cerqueira. 2007. Small mammal populations of an agroecosystem in the Atlantic Forest domain, Southeastern Brazil. Brazilian Journal of Biology 67: 179-186. doi: 10.1590/S1519-69842007000100025.

EISENBERG, J.F. \& K.H. REDFORD. 1999. Mammals of the Neotropics; The central neotropics: Ecuador, Bolivia, Brazil. Chicago, University of Chicago Press, vol. 3, 609p. 
FERNANDEZ, F.A.S. 1995. Métodos para estimativa de parâmetros populacionais por captura, marcação e recaptura. Oecologia Brasiliensis 2: 1-26.

FLeming, T.H. 1973. The reproductive cycles of three species of opossums and other mammals in the Panama Canal Zone. Journal of Mammalogy 54: 439-455.

Fonseca, G.A.B. \& M.C. KierulfF. 1989. Biology and natural history of Brazilian Atlantic Forest small mammals. Bulletin of Florida State Museum of Biological Sciences 34: 99152 .

Gentile, R.; P.S. D’Andrea; R.Cerqueira \& L.S. Maroja. 2000. Population dynamics and reproduction of marsupials and rodents in a Brazilian rural area: a five-year study. Studies on Neotropical Fauna and Environment 35: 1-9. doi: 10.1076/0165-0521(200004)35:1;1-M;FT001.

Gentile, R.; R. FinotTi; V. Rademaker, \& R. Cerqueira. 2004. Population dynamics of four marsupials and its relation to resource production in the Atlantic forest in southeastern Brazil. Mammalia 68: 109-119. doi: 10.1515/mamm.2004.012

Harris, M.B.; W.M. Tomas; G. MourÃo; C.J. Silva; E. Guimarães; F. SONODA \& E. FACHIM. 2005. Desafios para proteger o Pantanal brasileiro: ameaças e iniciativas em conservação. Megadiversidade 1: 156-164.

Herrera, H.M; V. Rademaker; U.G.P. Abreu; P.S. D' Andrea \& A.M. JANSEN. 2007. Variables that modulate the spatial distribution of Trypanosoma cruzi and Trypanosoma evansi in the Brazilian Pantanal. Acta Tropica 102: 55-62. doi: 10.1016/ j.actatropica.2007.03.001.

Keuroghlian, A.; D.P. Eaton \& A.L Desbiez. 2009. The response of a landscape species, white-lipped peccaries, to seasonal resource fluctuations in a tropical wetland, the Brazilian Pantanal. International Journal of Biodiversity and Conservation 1: 87-97.

LACHER, T.E \& C.J.R AlHo. 1989. Microhabitat use among small mammals in the Brazilian Pantanal. Journal of Mammalogy 70: 396-401.

Lee, A.K. \& A. Cockburn. 1985. Evolutionary ecology of marsupials. Cambridge, Cambridge University Press, 288p.

LEINER, N.O; E.Z.F SeTZ \& W.R. SiLVA. 2008. Semelparity and factors affecting the reproductive activity of the Brazilian Slender Opossum (Marmosops paulensis) in Southeastern Brazil. Journal of Mammalogy 89: 153-158. doi: 10.1644/07MAMM-A-083.1.

Lima, M.; N.C. Stenseth; N.G. Yoccoz \& F.M. Jaksic. 2001. Demography and population dynamics of the mouse opossum (Thylamys elegans) in semi-arid Chile: seasonality, feedback structure and climate. Proceedings of the Royal Society of London 268: 2053-2064. doi: 10.1098/ rspb.2001.1735.

Lorini, M.L.; J.A. Oliveira \& V.G. Persson. 1994. Annual age structure and reproductive patterns in Marmosa incana (Lund, 1841) (Didelphidae, Marsupialia). Zeitschrift für Saügetierkunde 59: 65-73.
Mares, M.A. \& K.A. Ernest. 1995. Population and community ecology of small mammals in a gallery forest of central Brazil. Journal of Mammalogy 76: 750-768.

Marinho Filho, J.; F.H.G. Rodrigues, \& K.M. Juarez. 2002. The Cerrado mammals: diversity, ecology and natural history, p. 266-284. In: P.S. Oliveira \& R.J. Marquis (Eds). The Cerrados of Brazil: Ecology and Natural History of a Neotropical Savanna. New York, Columbia University Press.

Martins, E.G.; V. Bonato; C. Queiroz-da-Silva \& S.F. Reis. 2006. Seasonality in reproduction, age structure and density of the gracile mouse opossum Gracilinanus microtarsus (Marsupialia: Didelphidae) in a Brazilian Cerrado. Journal of Tropical Ecology 22: 461-468. doi: 10.1017/S0266467406003269.

Mendel, S.M.; M.V. Vieira \& R. Cerqueira. 2008. Precipitation, litterfall, and the dynamics of density and biomass in the blackeared opossum, Didelphis aurita. Journal of Mammalogy 89: 159-167. doi: 10.1644/06-MAMM-A-263.1.

NIMER, E. 1989. Climatologia do Brasil. Rio de Janeiro, IBGE, Departamento de Recursos Naturais e Estudos Ambientais, 422p.

Nunes da Cunha, C.; P. Rawiel; K.M. Wantzen; W.J. Junk \& A. Lemes do Prado. 2006. Mapping and characterization of vegetation units by means of Landsat imagery and management recommendations for the Pantanal of Mato Grosso (Brazil), north of Poconé. Amazoniana 19: 1-32.

OAKS, J.R.; J.M. DAUL \& G.H. Adler. 2008. Life span of a Tropical Forest rodent, Proechimys semispinosus. Journal of Mammalogy 89: 904-908. doi: 10.1644/07-MAMM-A-045.1.

O'ConNell, M. 1989. Population dynamics of neotropical small mammals in seasonal habitats. Journal of Mammalogy 70: 532-548.

Pine, R.H.; P.L. Dalby \& J.O. Matson. 1985. Ecology, postnatal development, morphometrics and taxonomic status of the short-tailed opossum, Monodelphis dimidiata, an apparently semelparous annual marsupial. Annals of Carnegie Museum 54: 195-231.

Pinheiro, F.; I.R. Diniz; D. Coelho \& M.P.S. Bandeira. 2002. Seasonal pattern of insect abundance in the Brazilian Cerrado. Austral Ecology 27: 132-136. doi: 10.1046/j.14429993.2002.01165.x.

Pollock, K.H. 1982. A capture-recapture design robust to unequal probability of capture. Journal of Wildlife Management 46: 752-757.

Pотт, A. \& V.J. Ротт. 1994. Plantas do Pantanal. Corumbá, Embrapa Pantanal, 320p.

Rademaker, V. \& R. Cerqueira. 2006. Variation in the latitudinal reproductive patterns of the genus Didelphis (Didelphimorphia: Didelphidae). Austral Ecology 31: 337-342. doi: 10.1111/ j.1442-9993.2006.01562.x.

RoBerTS, M.S.; K.V. ThOMPSON \& J.A. CRANFORD. 1988. Reproduction and growth in captive punare (Thrichomys apereoides Rodentia: Echimyidae) of the Brazilian Caatinga with reference to the reproductive strategies of the Echimyidae. Journal of Mammalogy 69: 542-551. 
Rodela, L.G. \& J.P. Queiroz-Neto. 2007. Estacionalidade do clima no Pantanal da Nhecolândia, Mato Grosso do Sul, Brasil. Revista Brasileira de Cartografia 59: 101-113.

Schaller, G.B. 1983. Mammals and their biomass on a Brazilian Ranch. Arquivos de Zoologia 31: 1-36.

Seber, G.A.F. 1986. A review of estimating animal abundance. Biometrics 42: 267-292.

Seidl, A.F.; J.S.V. Silva \& A.S Moraes. 2001. Cattle ranching and deforestation in the Brazilian Pantanal. Ecological Economics 36: 413-425. doi: 10.1016/S0921-8009(00)00238-X.

SiLva, J.S.V \& M.M. Abdon. 1998. Delimitação do Pantanal Brasileiro e suas Sub-regiões. Pesquisa Agropecuária Brasileira 33: 1703-1711.

Sikes, R.S; W.L. Gannon \& The Animal Care and Use Committee of the American Society of Mammalogists. 2011. Guidelines of the American Society of Mammalogists for the use of wild mammals in research. Journal of Mammalogy 92: 235-253. doi: 10.1644/10-MAMM-F-355.1

Soriano, P.J. \& F.V. Clulow. 1988. Efecto de las inundaciones estacionales sobre poblaciones de pequeños mamíferos en los Llanos altos occidentales de Venezuela. Ecotropicos 1: 3-10.

Teixeira, B.R.; A.L.R. Roque; S.C. Barreiros-Gomez; P.M. Borodin; A.M. JANSEN \& P.S. D'ANDREA. 2005. Maintenance and breeding

Submitted: 22.II.2011; Accepted: 26.VI.2011.

Editorial responsibility: Diego Astúa de Moraes of Thrichomys (Trouessart, 1880) (Rodentia: Echimyidae) in captivity. Memórias do Instituto Oswaldo Cruz 100: 627630. doi: 10.1590/S0074-02762005000600005.

Tyndale-Biscoe, C.H. \& R.B. Mackenzie. 1976. Reproduction in Didelphis marsupialis and D. albiventris in Colombia. Journal of Mammalogy 37: 247-265.

VIEIRA, M.V. 1997. Dynamics of a rodent assemblage in a Cerrado of the southeast Brazil. Revista Brasileira de Biologia 57: 99-107.

Vieira, E.M.; M.A. Pizo \& P. Izar. 2003. Fruit and seed exploitation by small rodents of the Brazilian Atlantic Forest. Mammalia 67: 1-7.

Vivas, A.M. \& A.C. CALERo. 1985. Algunos aspectos de la ecologia poblacional de los pequeños mamíferos en la estación biológica de Los Llanos. Boletín de la Sociedad Venezuelana de Ciências Naturales 143: 79-99.

Vivas, A.M. 1986. Population biology of Sigmodon alstoni (Rodentia: Cricetidae) in the Venezuelan Llanos. Revista Chilena de Historia Natural 59: 179-191.

Vivas, A.M. \& A.C. Calero. 1988. Patterns in the diet of Sigmodon hispidus (Rodentia: Cricetidae) in relation to available resources in a tropical savanna. Ecotropicos 1: 82-90.

ZAR, J.H. 1999. Biostatistical analysis. New Jersey, Prentice Hall, $4^{\text {th }}$ ed., 662p. 